\section{Original researches}

\title{
Postnatal morphogenesis of lymph node parenchyma compartments in meat rabbit breeds
}

\author{
I. I. Myroshnychenko \\ Dnipro State Agrarian and Economic University, Dnipro, Ukraine
}

Received: 02 June 2020

Revised: 08 June 2020

Accepted: 25 June 2020

Dnipro State Agrarian and Economic University, S. Efremov Str. 25, 49600 Dnipro, Ukraine

Tel.: +38-099-054-38-41

E-mail: hibert.i.i@dsau.dp.ua

Cite this article: Myroshnychenko, I. I. (2020). Postnatal morphogenesis of lymph node parenchyma compartments in meat rabbit breeds. Theoretical and Applied Veterinary Medicine, 8(2), 179-184. doi: $10.32819 / 2020.25$

\begin{abstract}
The regularities of the formation and development of lymphoid lobules of lymph nodes parenchyma (somatic and visceral) in meat rabbits breeds during their postnatal period of ontogenesis were analyzed. We used standard histological research methods in combination with the impregnation of the midline histological sections with silver nitrate to visualize lymphoid lobules and their separate functional zones. The aim of the research was to establish the peculiarities of the histoarchitectonics of lymph nodes parenchyma in various localization according to the concept of their lobular structure in mammals and the patterns of the parenchymal lymphoid lobules transformations in the age aspect. The lymph nodes of 1-, 10-, 20-, 30-, 60- and 90-day-old meat rabbit breed (Hyplus cross) were examined. It was found that in the lymph nodes of one-day-old rabbits, the stromal component is formed by a capsule that surrounds poorly differentiated parenchyma a set of lymphoid cells and reticular fibers. Separation of lymphatic lobules and their structural and functional differentiation first appear in 10-day-old rabbits. In each lobule, units of the deep cortex (T-cell dependent zone), single lymphatic nodules (B-cell dependent zone), and medullary cords were indistinctly delimited among themselves. At the age of 20-days-old, the architectonics of lymphoid lobules was characterized by a more distinct differentiation of individual functional zones, and the number of lymphatic nodules without centers of reproduction was increased markedly. They were located exclusively at the upper pole of the lobules along the edge (subcapsular) sinusStarting from 30-days-old, at the structural and functional level of the organization, the lobules of the nodes parenchyma were completely divided into separate components: the centers of the units of the deep cortex, the paracortical and medullary cords, lymphatic nodules with and without centers, the interfollicular zone. From 60 to 90 days-old, qualitative and quantitative changes occurred in the deep cortex units, this was determined by an increase in their size, a significant increase in the number of lymphatic nodules with centers of reproduction, both on the periphery of lymphoid lobules and at the base of the medullary cords.
\end{abstract}

Keywords: structural and functional zones; lymphatic lobules; deep cortex units; segments; compartments; medullary cords, lymphatic nodules.

\section{Постнатальний морфогенез компартментів паренхіми лімфатичних вузлів кролів м'ясного напряму використання}

\section{І. І. Мирошниченко}

Дніпровський державний аграрно-економічний університет, Дніпро, Україна

Анотація. Проаналізовано закономірності формування та розвитку лімфоїдних часточок паренхіми лімфатичних вузлів (соматичних і вісцеральних) кролів м'ясного напрямку використання протягом постнатального періоду онтогенезу. Використано стандартні гістологічні методи досліджень у комплексі з імпрегнацією азотнокислим сріблом серединних гістозрізів лімфатичних вузлів для візуалізації лімфатичних часточок та їх окремих функціональних зон. Мета досліджень - встановлення особливостей гістоархітектоніки паренхіми лімфатичних вузлів різної локалізації згідно концепції про їх часточкову будову в ссавців та закономірностей перетворень лімфоїдних часточок паренхіми у віковому аспекті. Досліджували лімфатичні вузли 1-, 10-, 20-, 30-, 60- та 90-добових кролів м'ясного напрямку використання (крос Hyplus). Встановлено, що в лімфатичних вузлах добових кроленят сформованим являється стромальний компонент представлений капсулою, яка оточує слабодиференційовану паренхіму - сукупність лімфоїдних клітин і ретикулярних волокон. Відособлення лімфатичних часточок та їх структурно-функціональна диференціація вперше виявляються у кроликів 10-добового віку. У кожній часточці візуалізувалася нечітко відмежовані між собою одиниці глибокої кори (Т-залежна зона), поодинокі лімфатичні вузлики (В-залежна зона) та мозкові тяжі. У віці 20-ти діб архітектоніка лімфоїдних часточок характеризувалася більш чіткою диференціацією окремих функціональних зон, помітно збільшувалася кількість лімфатичних вузликів без центрів розмноження. Вони розміщувалися виключно на верхньому полюсі часточок вздовж крайового (підкапсулярного) синусу. Починаючи з 30-добового віку на структурно-функціональному рівні організації часточки паренхіми вузлів повністю розділені на окремі компоненти: центри одиниць глибокої кори, паракортикальні та мозкові тяжі, лімфатичні вузлики з центрами і без них, інферфолікулярну зону. 360 -ти до 90-то добового віку відбуваються якісні та кількісні зміни у одиницях глибокої кори, це визначається збільшенням їх розмірів, значним зростанням кількості лімфатичних вузликів із центрами розмноження, як на периферії лімфоїдних часточок, так і в основі мозкових тяжів.

Ключові слова: структурно-функціональні зони; лімфоїдні часточки; одиниці глибокої кори; сегменти; компартменти; мозкові тяжі; лімфатичні вузлики. 


\section{Вступ}

За сучасним уявленням лімфатичні вузли ссавців представленні комплексом трьох компонентів - сполучнотканинного каркасу (капсула, трабекули, ворітне потовщення капсули), системи лімфатичних просторів (синуси) та лімфоїдної паренхіми. Лімфоїдна паренхіма являє собою сукупність ретикулярної тканини, в комірках якої локалізуються різноманітні популяції лімфоцитів, що формують спеціалізовані Т- і В- клітинні зони, та ділянки, утворені з лімфоцитів різних популяцій та антитілпродукуючих клітин (Sixt, 2005; Zidan, 2012; Gavrilin et al., 2017a).

Для лімфатичних вузлів ссавців характерна регіонарна спеціалізація паренхіми та внутрішньоорганна диференціація, що виявляється у іiі часточковій будові (Gavrilin et al., 2017a). Визначено, що паренхіма лімфатичних вузлів формує відокремлені субодиниці паренхіми, які у світовому науковому співтоваристві позначаються як компартменти (Sainte-Marie, 2010) або лімфоїдні часточки (Willard-Mack, 2006). Інформація про особливості будови, розміщення, пренатальний морфогенез і вікові зміни лімфатичних часточок паренхіми лімфатичних вузлів здебільшого представлена результатами досліджень цих органів у матуронатних продуктивних ссавців (Lieshchova, 2007; Gavrylin et al., 2013).

Відомо, що компартменти паренхіми лімфатичних вузлів (лімфоїдні часточки) складаються 3 комплексу клітинних зон: високоспеціалізовані Т- і В-клітинні зони (одиниці глибокої кори чи паракортикальна зона) і лімфатичні вузлики (з центрами розмноження і без них), а також зони з гетерогенною популяцією лімфоцитів (кіркове плато, мозкові тяжі).

Розміщення лімфатичних часточок у лімфатичному вузлі прямо залежить від типу будови їх внутрішньовузлового лімфатичного русла. Так у лімфатичних вузлах, де основним місцем накопичення і розподілення лімфи являється підкапсулярний синус (колектор I типу) лімфоїдні часточки розміщені ланцюгом в один ряд уздовж нього, при чому окремі одиниці глибокої кори у їх складі можуть бути розвинені не однаково. Найбільш крупні одиниці можуть формувати додаткові бокові випинання, направлені вглибину паренхіми, в сторону мозкових тяжів (Gavrilin et al., 2017b). У лімфовузлах де основним накопичувальним резервуаром лімфи являється капсулярна (інтратрабекулярна) лімфатична цистерна (колектор II типу), лімфатичні часточки розміщуються в один ряд переважно вздовж перитрабекулярних синусів, де можуть формувати багаторівневі сфероподібні скупчення через виражену складчастість глибокої кори. Лімфатичні вузли 3 колекторами II типу характерні для свині (Hoshi, 1986), верблюдів (Gavrilin et al., 2013), слонів i носорога (Cave \& Aumonier, 1962a; 1962b), дельфіна (Moskov et al., 1969), у той час як лімфатичні вузли з колекторами I типу характерні для усіх інших ссавців (Willard-Mack, 2006; Patt \& Randolph, 2013; Gavrilin et al., 2017a).

Лімфатичні вузлики сконцентровані в кожній окремій часточці на полюсі, який наближений до крайового синусу, а на протилежному кінці розміщуються мозкові тяжі, що межують iз ворітним потовщенням. Одиниці глибокої кори розташовуються центрально формуючи загальну паракортикальну зону або так звану «глибоку кору» лімфатичних вузлів. Згідно $з$ дослідженнями Mebius, (2003) формування лімфоїдних часточок відбувається у пренатальному періоді онтогенезу. У лімфатичних вузлах плодів великої рогатої худоби відокремлення часточок із формуванням комплексу основних функціональних зон відбувається з 5-місячного віку (Lieshchova, 2007).

Особливості зональної структури паренхіми в лімфатичних вузлах імматуронатних продуктивних ссавців насьогодні досліджена недостатньо. Це негативно впливає на адекватність і об'єктивність оцінювання структурно-функціональних перетворень лімфоїдної тканини лімфатичних вузлів у процесі їх морфогенезу, а також при дії зовнішніх факторів і розвитку патологічних процесів.

Мета досліджень - встановити особливості гістоархітектоніки та вікові зміни паренхіми лімфатичних вузлів кролів м'ясного напрямку використання, 3 точки зору концепції про її часточкову будову.

\section{Матеріал і методи досліджень}

Дослідження проведені на базі Науково-дослідного центру біобезпеки та екологічного контролю ресурсів АПК Дніпровського державного аграрно-економічного університету. Досліджували соматичні (підколінні, нижньощелепні) та вісцеральні (каудальні брижові, каудальні середостінні) лімфатичні вузли, які методом анатомічного препарування відбирали від клінічно здорових новонароджених (добових), 10-, 20-, 30-, 60- і 90-добових кролів кросу Hyplus в умовах приватного господарства Запорізької області. Вік тварин датований за часом народження. Виготовляли тотальні парафінові (товщиною 3-10 мкм) і заморожені (товщиною 15-20 мкм) гістозрізи згідно 3 загальноприйнятими методиками (Horalskiy et al., 2019). 3piзи забарвлювали гематоксиліном та еозином, азур II-еозином та імпрегнували азотнокислим сріблом за Футом у модифікації П. М. Гавриліна (Gavrilin, 1999). На гістозрізах визначали особливості структурних перетворень ретикулярної строми лімфатичних вузлів з одночасною візуалізацію лімфоїдних часточок i їх окремих зон. Мікроскопію проводили за допомогою світлового мікроскопу Leica DM 1000 (окуляр $\times 10$, об'єктиви $\times 4, \times 10, \times 40)$. Для встановлення відносної площі стромальних і паренхіматозних компонентів лімфатичних вузлів, а також їх структурно-функціональних зон використовували стандартні окулярні сітки-вставки для диференційованого підрахунку крапок, що потрапили на всю площу органа та на площу окремих компонентів. Дослідження проводили на п’яти препаратах кожного органу з кожної вікової групи (Avtandilov, 1990). Статистичну обробку отриманих даних проводили шляхом визначення середнього арифметичного $(M)$ та його похибки $(m)$.

\section{Результати}

Лімфатичні вузли кролів першої доби життя представляють собою структури зі сформованими стромальними компонентами (капсула, трабекули) та малодиференційованою паренхімою у вигляді нагромадження клітин лімфоїдної тканини. У новонароджених кролів більш розвинуті стромальні компоненти характерні для соматичних лімфатичних вузлів. Вони мають щільну капсулу утворену неоформленою щільною волокнистою сполучною тканиною і досить розгалужені та тонкі трабекули, в той час як ворітне потовщення практично не виражене. Виявляється розподіл паренхіми лімфатичного вузла на зони: велику центральну - що відповідає мозковій речовині та дещо меншу периферичну, яка відповідає кірковій речовині. Мозкова речовина більш однорідна, не ущільнена, іiї основа - сітка звивистих ретикулярних волокон що сплітаючись, утворюють дрібні комірки. Кіркова речовина вузла навпаки, характеризується значною щільністю розміщення клітин, заселена великою кількістю лімфоцитів і зміщена до капсули вузла. Ретикулярні волокна цієї зони тонкі, їх просторова орієнтація - розміщення вертикально по відношенню до капсули вузла. Порівнюючи між собою соматичні та вісцеральні вузли у цьому віці можна визначити що для соматичних вузлів (підколінний) характерно значний і рівномірний розвиток строми, де капсула і трабекули дещо потовщені та займають більшу відносну площу (до 2,7\%), на відміну від вісцеральних (каудальний брижовий), де стромальні компоненти здебільшого значно тонші, від чого їх відносна площа менша $(1,8 \%)$. Ворітне потовщення не визначається ні у соматичних ні у вісцеральних лімфатичних вузлах. Для 
лімфатичних вузлів тварин цього віку характерний розвиток малодиференційованої паренхіми, загальний відносний об'єм якої, в 8-10 разів більше об'єму сполучнотканинної строми, у зв'язку з відсутністю виражених синусів у вузлах. Загальна відносна площа мозкової речовини у соматичних лімфатичних вузлах сягає майже $60 \%$, а у вісцеральних - менше $70-73,5 \%$.

3 досягненням 10-ти добового віку в лімфатичних вузлах кролів виявляються ознаки розподілу лімфоїдної тканини на часточки (компартменти) їх диференціація на функціональні зони. Часточки утворені одиницями глибокої кори, лімфатичними вузликами без центрів розмноження і мозковими тяжами. Вони неповністю відмежовані одна від одної стоншеними капсулярними трабекулами через недостатній розвиток останніх. У вісцеральних лімфатичних вузлах, на відміну від соматичних, капсулярні трабекули менш виражені, сполучнотканинна капсула тонша. Ворітне потовщення характеризується незначною площею $(0,8 \%)$ і овально-витягнутою формою у вісцеральних вузлах і дещо сплюснутою в соматичних. Найрозвиненішою клітинною зоною лімфатичних вузлів залишаються мозкові тяжі, їх відносна площа коливається від 55-56\% (соматичні) до 63-67\% (вісцеральні). У зв'язку із розвитком системи мозкових синусів, мозкові тяжі добре виражені, в них багато ретикулярних клітин, що утворюють щільну сітку. Переважаючі клітинні елементи - це клітини лімфоїдного ряду (малі, середні та великі лімфоцити) (Рис. 1). Основою лімфоїдних часточок являються округлі одиниці глибокої кори, розміщенні під крайовим синусом у вигляді ланцюжка, відмежовуючись від нього тонким стрічкоподібним кірковим плато. Порівнюючи ступінь диференціації паренхіми соматичних і вісцеральних лімфатичних вузлів у кролів цього віку, можна відзначити, що вони характеризуються здебільшого наявністю округлих (підколінний) та овальних (каудальний брижовий) одиниць глибокої кори. Для них притаманна однорідна будова, проте вже можна виявити зачатки центрів одиниць глибокої кори, що краще видно в соматичних лімфатичних вузлах. Також загальна відносна площа, яку займають одиниці глибокої кори в соматичних лімфатичних вузлах у 2 рази більша за таку у вісцеральних вузлах. Паракортикальні тяжі на периферії одиниць глибокої кори як у соматичних, так і у вісцеральних вузлах чітко не визначаються. У всіх лімфатичних вузлах 10-добових кроленят виявляються лімфатичні вузлики. Вони розміщуються поодиноко, наближені до ділянки кіркового плато вздовж крайового синусу, не мають центрів розмноження. На відміну від соматичних лімфатичних вузлів у вісцеральних деякі лімфатичні вузлики розміщуються поблизу нижньої ділянки одиниць глибокої кори.

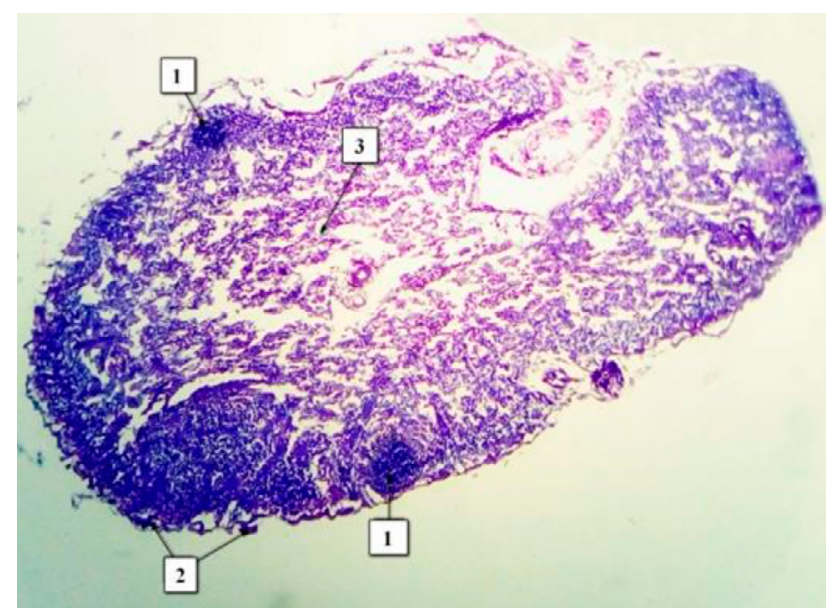

Рис. 1. Підколінний лімфатичний вузол 10-добового кроля. Гематоксилін та еозин, $\times 100 ; 1-$ лімфатичні вузлики без центрів розмноження, 2 - капсула лімфатичного вузла, 3 - мозкова речовина
Архітектоніка лімфоїдних часточок у лімфатичних вузлах кролів по досягненню 20-добового віку характеризується диференціацією кіркової речовини на одиниці глибокої кори і лімфатичні вузлики без центрів розмноження, кількість і відносна площа яких, збільшується, порівняно із 10-добовими тваринами. Лімфатичні вузлики розміщуються переважно на верхівці кіркового плато з наближенням до крайового синусу, що добре виражено у каудальному брижовому лімфатичному вузлі (Рис.2).

Лімфоїдні часточки паренхіми лімфатичних вузлів представлені овально-витягнутими утвореннями - одиницями глибокої кори та невеликими лімфатичними вузликами, розташованими поодиноко на верхньому полюсі вздовж крайового синусу. Мозкові тяжі окремих лімфатичних часточок не відмежовані між собою, їх загальна відносна площа, порівняно iз попереднім віком зменшується (до $55-56 \%$ у соматичних і 63-67\% у вісцеральних вузлах), проте залишається найбільшою функціональною зоною (Рис. 3).

Для лімфатичних вузлів кролів 30-добового віку характерно зменшення відносної площі лімфоїдної тканини за рахунок розвитку синусів у вузлах і потовщенню сполучнотканинної строми. Часточки паренхіми лімфатичних вузлів розташовані в один ряд вздовж підкапсулярного синуса, відділені один від одного достатньо сформованими капсулярними трабекулами, характеризуються наявністю усіх функціональних зон. Найбільшою за площею залишається зона мозкових тяжів, хоча її відносна площа поступово зменшується. У соматичних вузлах кролів цього віку вона складає близько $43 \%$, а у вісцеральних - 45-49\% (Рис. 4). Одиниці глибокої кори чітко розділені на центральну зону та паракортикальні тяжі, розміщені по бокам центру, вздовж проміжних кіркових синусів. Від крайового синуса центр одиниці глибокої кори відділений інтерфолікулярною зоною, на якій формуються лімфатичні вузлики. Центри одиниць глибокої кори краще розвинуті у соматичних лімфатичних вузлах, де їх відносна площа може сягати майже $29 \%$, а у вісцеральних - не перевищує $17 \%$. Відносна площа паракортикальних тяжів та інтерфолікулярної зони майже однакова, і у соматичних лімфовузлах становить $2,5-3 \%$, а у вісцеральних $-3-3,5 \%$.

Характерно, що у лімфоїдних часточках лімфовузлів починають активно 3'являтись лімфатичні вузлики 3 центрами розмноження, вони розміщуються у більш глибоких ділянках одиниць глибокої кори переважно на верхньому полюсі. Їх відносна площа більша у вісцеральних лімфатичних вузлах $(6,7-$ $7 \%)$, порівняно із соматичними (5-6,4\%) (Рис. 5).

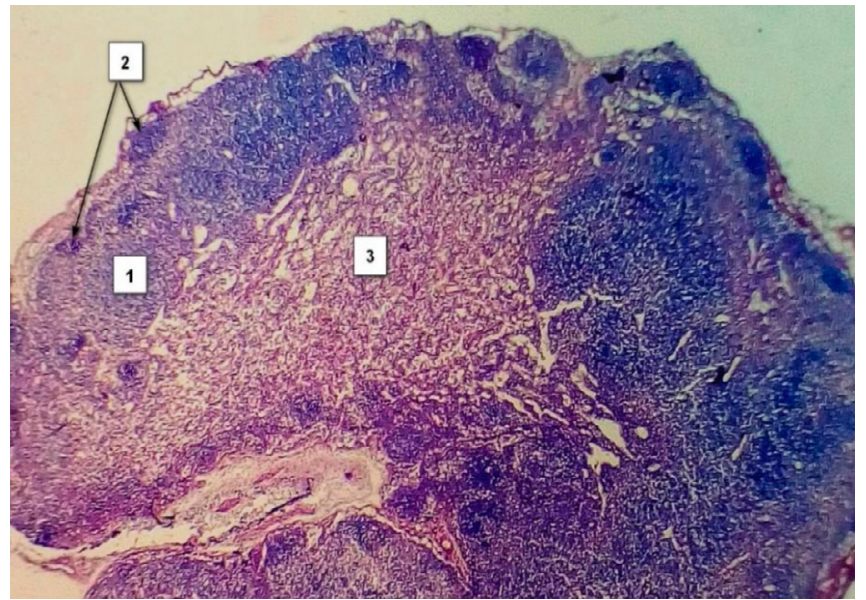

Рис. 2. Каудальний брижовий лімфатичний вузол 20 -добового кроля. Гематоксилін і еозин, $\times 100 ; 1$ - одиниці глибокої кори, 2 - лімфатичні вузлики без центрів розмноження, 3 - мозкові тяжі. 


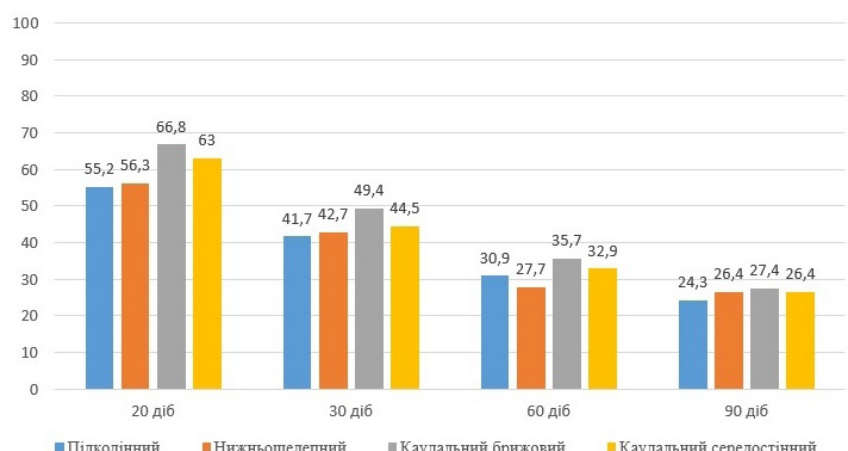

Рис. 3. Динаміка відносної площі мозкових тяжів у лімфатичних вузлах кролів протягом 20 - 90-добового віку, \%

Отже починаючи з 30-добового віку в лімфатичних вузлах кролів відмічено відособлення лімфоїдних часточок паренхіми із формуванням основних функціональних зон. Розташування лімфоїдних часточок визначається в один шар, тому їх гістоархітектоніка нагадує пірамідальні часточки що розташовуються по колу.

Починаючи з 60-добового віку у кролів м'ясного напрямку використання у зв'язку з періодом інтенсивного росту, як у соматичних, так і у вісцеральних лімфатичних вузлах збільшується кількість і відносна площа лімфатичних вузликів із центрами розмноження (до $8,6-12,5 \%$ у соматичних, до $10,6-13 \%$ у вісцеральних вузлах) (див. рис. 5).

Відбувається потовщення паракортикальних тяжів та збільшується об'єм інтерфолікулярної зони, їх загальна відносна площа зростає майже до 8-10\%. У вісцеральних лімфатичних вузлах відбувається формування лімфатичних вузликів без центрів розмноження на основі мозкових тяжів (каудальний брижовий), вони розміщуються досить хаотично, проте наближені до паракортикальних тяжів, фактично оточуючи одиниці глибокої кори з усіх боків. Відносна площа лімфатичних вузликів без центрів розмноження складає близько $7 \%$ у соматичних $\mathrm{i}$ 5-8\% у вісцеральних вузлах (Рис. 6). Найрозвиненішою функціональною зоною залишаються мозкові тяжі, з відносною площею $28-30 \%$ у соматичних вузлах, і $33-36 \%$ у вісцеральних. $\mathrm{y}$ деяких ділянках паренхіми лімфатичних вузлів у цьому віці спостерігається формування «додаткових» часточок, невеликих за розміром у яких в ділянці підкапсулярного синусу, формуються дрібні лімфатичні вузлики без центрів розмноження. Вони оточують часточки по колу, надаючи загальному вигляду лімфатичного вузла шахової дошки утворюючи пошарову будову (Рис. 7).

У 90-добових кролів гістоархітектоніка паренхіми лімфа-

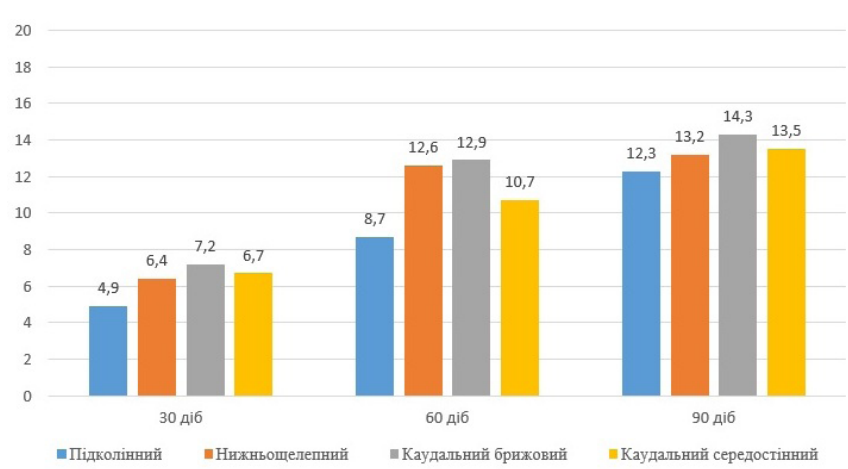

Рис. 5. Динаміка відносної площі лімфоїдних вузликів із центрами розмноження у лімфатичних вузлах кролів протягом 20 - 90-добового віку, \%

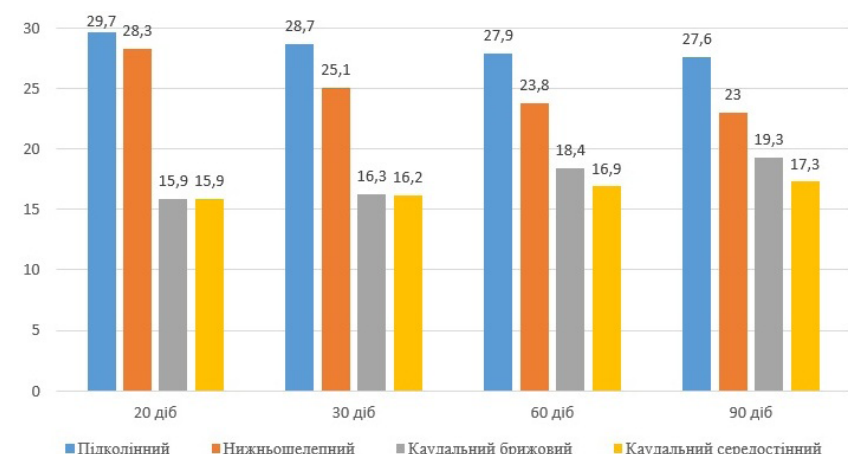

Рис. 4. Динаміка відносної площі центрів одиниць глибокої кори в лімфатичних вузлах кролів протягом 20 - 90-добового віку, \%

тичних вузлів фактично не змінна. Значно збільшується кількість лімфатичних вузликів із центрами розмноження, що переважно локалізуються по периферії лімфоїдних часточок як на основі інтерфолікулярної зони і паракортикальних тяжів, так і на основі мозкових тяжів. У кількісному відношенні у лімфоїдних часточках: збільшується відносна площа інтерфолікулярної зони та паракортикальних тяжів до 5 і 7\% відповідно у соматичних і до 4 і 5\% у вісцеральних вузлах; зростає відносна площа лімфатичних вузликів із центрами розмноження до $13 \%$ у соматичних, і 14,5\% у вісцеральних вузлах; зменшується відносна площа лімфатичних вузликів без центрів розмноження до $6 \%$ у соматичних і до 6,5\% у вісцеральних вузлах; знижується відносна площа мозкових тяжів до $26 \%$ у соматичних і до $27 \%$ у вісцеральних вузлах; відносна площа центрів одиниць глибокої кори практично не змінюється $23-28 \%$ соматичних, та $17-19 \%$ вісцеральних вузлах.

Архітектоніка ретикулярних волокон паренхіми лімфатичних вузлів 3 досягненням фізіологічної зрілості у кролів характеризується зменшенням у розмірах комірок і загальним ущільненням сітки ретикулярних волокон у сформованих ретикулярних кошиках на периферії одиниць глибокої кори. А ретикулярні сітки у ділянці лімфатичних вузликів із центрами розмноження фактично не визначаються, виявляються лише як поодинокі та стоншені волокна (Рис. 8).

Згідно проведеного дослідження, можна зазначити що будова паренхіми у лімфатичних вузлах кролів м'ясного напрямку використання має часточкову будову, яка відповідає структурі цих органів інших ссавців. Одночасно з цим, лімфатичні вузли кроликів мають характерні особливості, що притаманні імматуронатним тваринам. Встановлено, що часточкова будова паренхіми лімфатичних вузлів цих тварин визначається з моменту народження, причому спеціалізовані клітинні зони, у межах

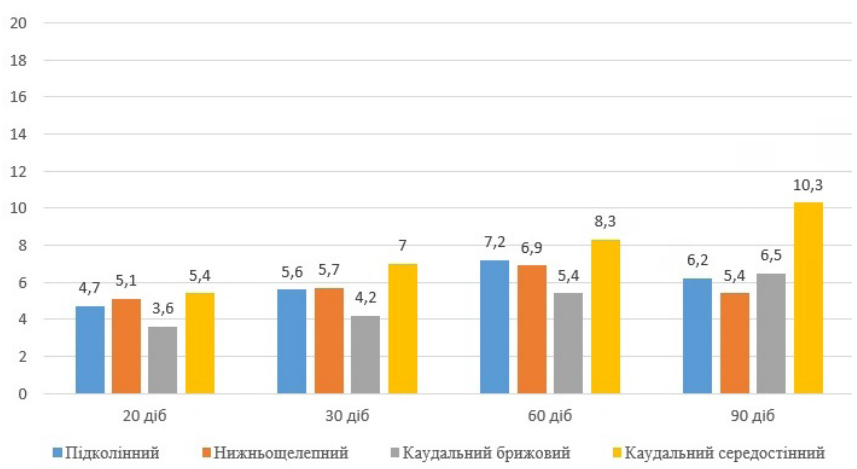

Рис. 6. Динаміка відносної площі лімфоїдних вузликів без центрів розмноження у лімфатичних вузлах кролів 20 - 90-добового віку, \% 


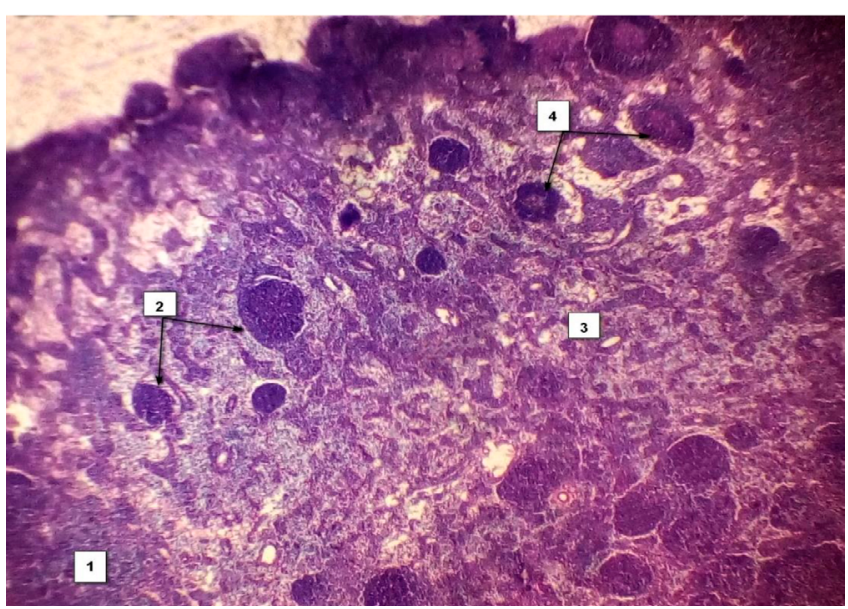

Рис. 7. Каудальний брижовий лімфатичний вузол 60-добового кроля. Гематоксилін та еозин, $\times 100.1$ - одиниця глибокої кори, 2 - лімфатичні вузлики без центрів розмноження, 3 мозкові тяжі, 4 - лімфатичні вузлики з центрами розмноження

часточок, за ступенем розвитку знаходяться на дуже низькому рівні організації, що пов'язано з незначним упливом антигенів під час внутрішньоутробного розвитку. У період постнатального розвитку організація часточок паренхіми лімфатичних вузлів у кролів, пов'язана 3 початком активного розвитку лімфатичних вузликів на основі інтерфолікулярної зони починаючи з 10-добового віку, по периферії одиниць глибокої кори (паракортикальні тяжі) до 30-ї доби, у деяких лімфатичних вузлах (вісцеральних) на основі мозкових тяжів з 60-ї доби, незмінною архітектонікою до 90-добового віку. Також відбуваються якісні та кількісні зміни одиниць глибокої кори які до 60-добового віку значно збільшуються у своїх розмірах без значних змін локалізації (під крайовим синусом уздовж кіркового плато у один ряд). Надалі відбувається процес збільшення розмірів одиниць глибокої кори у товщі паренхіми лімфатичних вузлів на межі підкапсулярного синусу.

\section{Обговорення}

Згідно результатів наших досліджень лімфатичні вузли кролів на органному рівні структурної організації представлені досить щільними, компактними утворами. Порівнюючи соматичні та вісцеральні лімфатичні вузли кролів, можливо відзначити що перші - це поодинокі, повністю відокремлені органи, в той час як для вісцеральних характерні скупчення різних за розміром лімфатичних вузлів, що утворюють щільно розміщені у жировій тканині великі пакети (брижові лімфатичні вузли), або утворення у вигляді грони (середостінні лімфатичні вузли), не утворюючи при цьому конгломератів (Gavrilin \& Gibert, 2016).

Для лімфоїдної паренхіми лімфатичних вузлів кролів характерна специфічна гістоархітектоніка що характеризується чітко вираженою морфологічною полярністю. Усі без винятку лімфатичні вузли побудовані за єдиним принципом і представлені сукупністю функціональних зон лімфоїдної паренхіми зі специфічною архітектонікою сіток ретикулярних волокон, які розміщені в певному порядку відносно один до одного, утворюючи при цьому функціональні сегменти або компартменти вузлів (Gavrilin \& Gibert, 2016).

Відомо, що для паренхіми лімфатичних вузлів коней, свиней і бика домашнього (Equus caballus L., Sus domesticus L., Bos primigenius taurus $L$.), що відносять до продуктивних тварин характерна часточкова будова. Зважаючи на те що ці види тварин

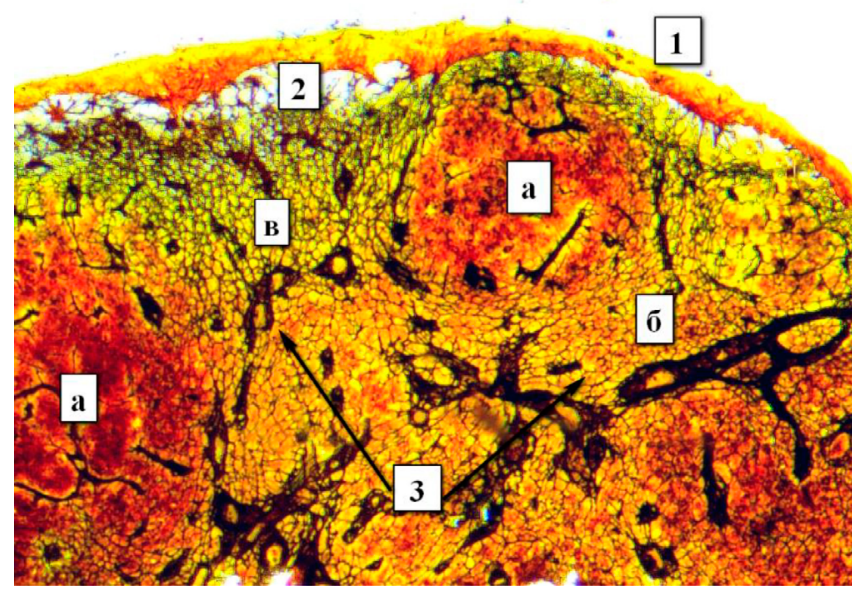

Рис. 8. Підколінний лімфатичний вузол 90 -добового кроля. Імпрегнація азотнокислим сріблом, × 100. 1 - капсула, 2 підкапсулярний синус, 3 - лімфоїдна часточка: а - лімфатичні вузлики, б - одиниця глибокої кори, в - кіркове плато.

являються матуронатними, повне формування лімфатичних вузлів відбувається до моменту народження, проте розвиток спеціалізованих клітинних зон у межах часточок залишається мінімальним, що обумовлено низьким ступенем антигенної стимуляції вторинних лімфоїдних органів у ссавців у період внутрішньоутробного розвитку (Sapin, 1978; Gavrilin et al., 2017a). Гістоархітектоніка лімфоїдної паренхіми в лімфатичних вузлах цих тварин характеризується вираженою морфологічною полярністю, яка має прояв у наростанні ії обсягу та щільності до центрів приносних лімфатичних судин 3 формуванням, відповідно, кіркової речовини, що характеризується щільністю лімфоцитів і розрідженої мозкової речовини вузлів. Відносно цього функціональні зони паренхіми лімфатичних вузлів у бика і коня наближені до крайового синусу, а у свині, в зв'язку зі специфікою лімфодинаміки - до ворітного (Hoshi et al., 1986; Vyrenkov et al., 1995; Gavrilin et al., 2017b).

Дослідженнми гістоархітектоніки соматичних і вісцеральних лімфатичних вузлів нутрій 30-добового віку встановлено, що усі функціональні зони вузлів повністю сформовані. Відзначено наявність у кірковій речовині значної кількості вторинних лімфатичних вузликів, а в мозковій - первинних (Kiseleva \& Panfilov, 2008).

Відомо, що лімфатичні вузли кролів мають тонку хвилясту капсулу, вузький крайовий синус у вигляді щілини, кіркова речовина розділена на декілька фрагментів. Порівнюючи між собою лімфатичні вузли (соматичні) деякі дослідники визначили різницю між розвитком тих чи інших структурних компонентів між собою у різних лімфатичних вузлах (у пахових - досить добре розвинута кіркова речовина, у підпахвинних - навпаки краще розвинута мозкова речовина). Для всіх соматичних лімфатичних вузлів характерна невелика кількість лімфатичних вузликів зі світлими центрами, тонкі мозкові тяжі $з$ широкими синусами, а також густа сітка ретикулярних волокон (Sapin et al., 1978)

Marasulov (2011) у своїх дослідженнях встановив, що лімфатичні вузлики в лімфатичних вузлах кролів різняться за розміром: малі, середні та великі з характерними особливостями. Великі вузлики (активно функціонуючі) мають чітко виражені гермінативні центри 3 мантійними зонами та великою кількістю фігур мітозу та апоптозу. Вузлики середнього розміру (помірно функціонуючі) зі слабо вираженими гермінативними центрами, в яких зазвичай проліферативна активність незначна. Вони мають товстий шар клітин, які досить щільно розта- 
шовані утворюючи мантійну та маргінальну зони. До третього типу відносяться малі вузлики (не функціонуючі або сплячі), які характеризуються компактно заселеними лімфоцитами.

Отже, гістоархітектоніка лімфоїдної паренхіми лімфатичних вузлів кролів м'ясного напрямку використання подібна до такої інших видів ссавців. Визначено, що повне формування всіх структурних зон (кіркове плато, одиниці глибокої кори, лімфатичні вузлики (з центрами та без центрів розмноження) відбувається після досягнення 30-добового віку.

Встановлений характер гістоархітектоніки паренхіми лімфатичних вузлів у кролів м'ясного напрямку використання можливо обумовлений імунною функцією цих органів у незрілонароджених ссавців, що виражаються у незначній імунологічній реактивності.

\section{Висновки}

У лімфатичних вузлах кролів, що відносять до імматуронатних ссавців ознаки морфологічної диференціації паренхіми проявляються від самого народження, а по досягненні 30-добового віку остаточно набувають структурно-функціональної спеціалізації всіх структурних стромально-паренхіматозних компонентів.

Розвиток лімфоїдної паренхіми у лімфатичних вузлах кролів відбувається у декілька послідовних етапів: накопичення лімфоїдної паренхіми вздовж крайового синусу без формування видимої часточкової структури (з 1-ї по 10-ту добу); розподіл лімфоїдної тканини 3 диференціацією їі на часточки чи компартменти (з 10-ї по 20-ту добу); ріст і розвиток лімфатичних вузликів без центрів розмноження на основі інтерфолікулярної зони внаслідок чого, будова часточок паренхіми представлена великими овально-витягнутими одиницями глибокої кори та дрібними лімфатичними вузликами, розміщеними поодиноко на верхньому полюсі вздовж крайового синусу (з 20-ї по 30ту добу); збільшення лімфатичних часточок, розвиток і збільшення інтерфолікулярної зони та паракортикальних тяжів, 3 одночасним зменшенням площі мозкових тяжів та остаточне формування і диференціація всіх структурних компонентів (3 30-ї по 60-ту добу); збільшення кількісті та відносної площі лімфатичних вузликів із центрами розмноження, потовщення паракортикальних тяжів і збільшення об'єму інтерфолікулярної зони (з 60-ї по 90-ту добу). Гістоархітектоніка лімфоїдних часточок за весь період постнатального онтогенезу у кролів характеризується одношаровим та однорядним їх розміщенням.

\section{References}

Avtandilov, G. G. (1990). Meditsinskaya morfometrya [Medical morphometry]. Medicine, Moscow (in Russian).

Cave, A. J. E., \& Aumonier, F. J. (1962a). Elephant and rhinoceros lymph-node histology. Journal of the Royal Microscopical Society, 80(3), 209-214.

Cave, A.J.E., \& Aumonier, F.J. (1962b). Lymph node structure in the sumatran rhinoceros. Journal of Microscopy, 81, 73-77.

Gavrilin, P., \& Gibert, I. (2016). The study of topography features and macro structure of the lymph nodes of rabbits for meat use (cross hyplus). Theoretical and Applied Veterinary Medicine, 4(4), 12-17 (in Ukrainian).

Gavrylin, P., Lieshchova, M., Rahmoun, D. E., \& Benchadi, H. (2013). Features topography and macrostructure of lymph nodes in Camels (Camelus dromedarius). Online Journal of Animal and Feed Research, 3(2), 106-110.

Gavrilin, P. N. (1999). Modificatsiya sposoba impregnatsii serebrom po Futy gistotopogramm organov krovetvoreniya, izgotovlennyih na microtomekriostate [Modification of the silver impregnation method according to Futhistotopograms of hemopoietic organs made on a microtome cryostat].Vestnik Morphologii, 5(1), 106-108 (in Russian).

Gavrilin, P. N., Gavrilina, O. G., \& Kravtsova, M. V. (2017a). The compartments of the parenchyma of the lymph nodes in the newborn domestic bull (Bos taurus). Regulatory Mechanisms in Biosystems, 8 (2), 169-178.

Gavrilin, P. N., Gavrilina, E. G., \& Evert, V. V. (2017b). Histoarchitectonics of the parenchyma of lymph nodes of mammals with different structure of intranodal lymphatic channel. Ukrainian Journal of Ecology, 7(3), 96-107.

Horalskiy, L. P., Khomych, V. T., \& Kononsky, A. I. (2019). Histological techniques and morphological methods in normal and pathological conditions. Zhitomir, Polissia (in Ukrainian).

Hoshi, N., Hashimoto, Y., Kitawa, H., Kon, Y., Kudo, N. (1986). Histological and immunohistochemical studies on the architecture of lymph nodes in pig. Japan Journal Veterinary Science, 48 (6), 1097-1107.

Moskov, M., Schiwatschewa, T., \& Bonev, S. (1969). Vergleichshistologische untersuchung der lymphknoten der sauger. Die lymphknoten des dolphins. Anatomischer Anzeiger, $124,49-67$.

Kiseleva,Y. A., \& Panfilov, A. B. (2008). Citoarhitektonika limfaticheskih uzlov perednego otdela zheludochnokishechnogo trakta nutrij $\mathrm{v}$ ontogeneze [Cytoarchitectonics of lymph nodes in the front section of nutria (coypu) alimentary canal in ontogenesis]. Izvestiya Orenburskogo Gosudarstvennogo Agrarnogo Universiteta, 4 (20), 93 - 96 (in Russian).

Marasulov, A. A. (2011). Morphology of organs and tissues of rabbit immune system in age aspect. Extended abstract of candidate's thesis. Kyrgyzskij Nacionalnyj Agrarnyj Universitet, Bishkek (in Russian).

Mebius, R. E. (2003). Erratum: Organogenesis of lymphoid tissues. Nature Reviews Immunology, 3(4), 292-303.

Lieshchova, M. O. (2007). Features of the morphogenesis of bovine fetal lymphoid organs. Extended abstract of candidate's thesis. NAU, Kyiv (in Ukrainian).

Platt, A.M., \& Randolph, G. J. (2013). Dendritic cell migration through the lymphatic vasculature to lymph nodes. Advances in Immunology, 120, 51-68.

Sainte-Marie, G. (2010). The lymph node revisited: Development, morphology, functioning, and role in triggering primary immune responses. The Anatomical Record, 293(2), 32-37.

Sapin, M. R., Jurina, N. A., \& Etingen, L. (1978). Limfaticheskij uzel [Lymph node]. Medicine, Moscow (in Russian).

Sapin, M. R. (2006). Osobennosti imunnogo otveta pri razlichnych vnechnich vozdeistviyah [Features of the immune response under various external influences]. Morphology, 129(4), 109110 (in Russian).

Sixt, M., Kanazawa, N., Selg, M., Samson, T., Roos, G., Reinhardt, D. P., Pabst, R., Lutz, M. B., \& Sorokin, L. (2005). The conduit system transports soluble antigens from the afferent lymph to resident dendritic cells in the $\mathrm{T}$ cell area of the lymph node. Immunity, 22(1), 19-29.

Vyrenkov, Y. E., Shishlo, V. K., Antropova, J. G., \& Ryzhova, A. V. (1995). Sovremennye dannye o strukturno-funkcional'noj organizacii limfaticheskogo uzla [Modern data on the structural and functional organization of the lymph node]. Morphology, 103(3), 34-40 (in Russian).

Willard-Mack, C.L. (2006). Normal structure, function, and histology of lymph nodes. Toxicologic Pathology, 34(5), 409424.

Zidan, M., \& Pabst, R. (2012). Histological, histochemical and immunohistoche-mical study of the lymph nodes of the one humped camel (Camelus dromedarius). Veterinary Immunology and Immunopathology, 145(1-2), 191-198. 